\title{
PENGARUH BAURAN PROMOSI TERHADAP PENINGKATAN PENJUALAN KAMAR DI HOTEL BENUA BANDUNG
}

\author{
Dani Rahadian; Adithya Pratomo \\ Hotel Management Department, Faculty of Economic and Communication, BINUS University \\ Jln. K. H. Syahdan No. 9, Palmerah, Jakarta Barat 11480 \\ rahadian.dani@gmail.com; pratomo.adithya@yahoo.com
}

\begin{abstract}
The purpose of this research is to find out the influence of promotion mix on the increase of room sale at Hotel Benua Bandung. The results of this research are expected to be used as consideration by the hotel manager in determining the influence of promotion mix on room sale, as well as using some other variables in promotion mix. This research was based on the use of data of all promotion costs and room sales at Hotel Benua Bandung during the past five years. Data were then processed by calculating the percentage using basic regression method on SPSS program. The findings proved a positive influence of promotion mix on the increase of room sales at Hotel Benua Bandung.
\end{abstract}

Keywords: promotion mix, room sales

\begin{abstract}
ABSTRAK
Tujuan penelitian ini adalah untuk mengetahui pengaruh bauran promosi terhadap peningkatan penjualan kamar di Hotel Benua Bandung. Hasil penelitian diharapkan dapat menjadi pertimbangan bagi manajer hotel dalam menentukan pengaruh bauran promosi terhadap penjualan kamar, serta menggunakan beberapa variabel lainnya dari bauran promosi. Penelitian ini didasarkan pada penggunaan data semua biaya promosi yang dikeluarkan serta hasil penjualan kamar di Hotel Benua Bandung dalam lima tahun terakhir. Data tersebut kemudian diolah dengan menghitung persentase menggunakan metode regresi sederhana pada program SPSS. Hasil yang diperoleh membuktikan adanya pengaruh positif bauran promosi terhadap peningkatan penjualan kamar di Hotel Benua Bandung.
\end{abstract}

Kata kunci: bauran promosi, penjualan kamar 


\section{PENDAHULUAN}

Dalam perkembangan kepariwisataan, selain pengembangan usaha daya tarik wisata, diperlukan adanya keseimbangan pengembangan usaha sarana akomodasi bagi para wisatawan yang berkunjung ke Indonesia. Hotel, sebagai salah satu jenis akomodasi yang awalnya hanya didirikan di sekitar jalan yang masih primitif dengan pengelolaan yang sederhana, pada pengembangan selanjutnya dibangun di sekitar pelabuhan, stasiun kereta api, bandar udara, dan di daerah-daerah dengan sarana pelayanan yang baik dan lengkap. Industri perhotelan memiliki karakteristik tersendiri, yang berbeda dengan sektor industri lainnya. Industri jasa ini menghasilkan dan memasarkan produknya bersamaan dengan tempat dan waktu dihasilkannya produk. Industri ini selain padat modal juga padat karya, sehingga memerlukan modal dan tenaga kerja dengan jumlah yang besar pula.

Industri perhotelan, baik nasional maupun internasional, mengalami persaingan yang ketat di antara mereka. Keadaan ini mendorong perusahaan untuk selalu jeli dan tanggap dalam mencermati berbagai perubahan baik internal maupun eksternal, guna mempertahankan kelangsungan hidup perusahaan. Pihak manajemen hotel harus terus menerus melakukan pemasaran dan promosi yang aktif karena sektor industri jasa diharapkan dapat meningkatkan daya tahan perekonomian nasional, memperluas lapangan kerja dan kesempatan usaha, serta sekaligus mendorong berkembangnya kegiatan ekonomi dalam berbagai sektor pembangunan lainnya.

Di sini setiap perusahaan dihadapkan pada tantangan dalam menghadapi persaingan dari unitunit usaha hotel sejenis dalam rangka meningkatkan penjualannya. Dengan adanya keadaan pasar yang demikian, perusahaan harus pandai-pandai menyesuaikan diri agar dapat bertahan dalam persaingan. Salah satu unsur kegiatan yang menentukan keberhasilan suatu perusahaan adalah kegiatan promosi. Kegiatan promosi tidak hanya digunakan perusahaan untuk mengejar laba, tetapi juga lebih memperkenalkan produk jasa perusahaan kepada konsumen.

Hotel Benua yang terletak di Jln. Pelajar Pejuang 45 No.111 tergolong city hotel berdasarkan letaknya di tengah kota dengan tipe tamu bisnis dan transit. Lama tamu yang tinggal di Hotel Benua Bandung adalah dua hingga tujuh hari sehingga hotel digolongkan ke dalam semi residentel hotel. Dengan makin ketatnya persaingan usaha dalam bidang jasa perhotelan, strategi promosi merupakan salah satu cara untuk menarik minat konsumen terhadap produk jasa yang ditawarkan. Promosi ini pula diharapkan dapat merebut, mempertahankan, sekaligus dapat meningkatkan volume penjualan. Berdasarkan uraian latar belakang, penelitian mengangkat judul Pengaruh Bauran Promosi Terhadap Peningkatan Penjualan Kamar pada Hotel Benua Bandung.

Berdasarkan latar belakang yang telah dikemukakan, yang menjadi rumusan masalah dalam penelitian ini adalah apakah bauran promosi yang dilakukan Hotel Benua Bandung (periklanan, penjualan individu, dan promosi penjualan) mempunyai pengaruh terhadap peningkatan penjualan kamar. Tujuan penelitian adalah mengetahui pengaruh bauran promosi (periklanan, penjualan individu dan promosi penjualan) terhadap perkembangan penjualan kamar di Hotel Benua Bandung. Sementara manfaat penelitian adalah menjadi bahan bacaan dan referensi bagi penelitian selanjutnya dan dapat dikembangkan untuk penelitian lain. Selain itu, penelitian diharapkan dapat menjadi sarana pembelajaran untuk memperluas wawasan dan pengetahuan tentang promosi.

\section{Tinjauan Pustaka}

Sebagaimana telah diketahui bahwa keberhasilan suatu perusahaan dalam mencapai tujuan dan sasaran perusahaan sangat dipengaruhi oleh kemampuan perusahaan memasarkan produknya kepada kosumen. Untuk memberikan penjelasan pengertian mengenai pemasaran maka penelitian mengemukakan berapa pendapat mengenai pemasaran. Hermawan Kertajaya dalam Alma (2004:3), 
merumuskan: "Pemasaran adalah sebuah disiplin bisnis strategis yang mengarahkan proses penciptaan, penawaran, dan perubahan values dari inisiator kepada stake holder."

Lebih lanjut dijelaskan tentang istilah atau kata yang terdapat dalam definisi tersebut. Strategi berarti sebuah konsep superordinat yang mencakup keseluruhan kebijaksanaan yang perlu dirinci lagi dalam taktik-taktik untuk dilaksanakan. Bisnis berarti berlaku untuk setiap entitas bisnis, profit ataupun nonprofit. Mengarahkan berarti pemasaran adalah umbrella guidance (payung panduan) bagi setiap aktivitas yang ada pada seluruh organisasi perusahaan. Menciptakan pemasaran adalah panduan untuk produksi. Menawarkan pemasaran adalah panduan untuk proposisi. Mempertukarkan, pemasaran adalah sebuah panduan untuk transaksi. Inisiator, pemasaran dapat digunakan oleh perusahaan, individu, orang, Negara, dan sebagainya. Stakeholders, pemasaran dapat digunakan untuk menciptakan, menawarkan, mempertukarkan nilai kepada para pelanggan, karyawan, shareholder, pemasok, dealer, bankir, pemerintah, publik, dan sebagainya.

Menurut Hermawan Kertajaya, pemasaran sebagai suatu konsep yang adaptif di masa depan akan berlandaskan pada filosofi sebagai berikut. Visi; pemasaran harus menjadi suatu konsep bisnis strategis yang bisa memberikan kepuasan berkelanjutan dan bukan kepuasan sesaat untuk tiga stakeholder utama di setiap perusahaan, yaitu pelanggan, karyawan, dan pemilik perusahaan. Misi; pemasaran akan menjadi jiwa bukan sekadar "salah satu anggota tubuh" suatu perusahaan; karena itu setiap orang di dalam perusahaan akan menjadi pemasar. Nilai; nilai utama yang dianut perusahaan adalah (1) merek lebih berharga dari pada produk bagi pelanggan; (2) apapun bisnis yang dijalankan, pemilik perusahaan harus menganggapnya sebagai bisnis jasa; (3) setiap orang di dalam perusahaan harus merasa terlibat dalam proses pemuasan pelanggan, baik secara langsung maupun tidak langsung, bukan hanya sebagai pelaksana dari suatu fungsi tertentu.

Swasta dan Irawan dalam Khotijah (2004:11) mendefinisikan pemasaran sebagai:

"Pemasaran adalah sebagai suatu sistem dari kegiatan-kegiatan yang saling berhubungan ditujukan untuk merencanakan, menentukan harga, mempromosikan, mendistribusikan barang dan jasa kepada kelompok pembeli merupakan inti dari sistem pemasaran perusahaan, yaitu produk, struktur harga, kegiatan promosi, dan sistem distribusi."

Philip Kotler dalam Khatijah (2004:8) mendefinisikan pemasaran sebagai berikut:

\begin{abstract}
"Dari sudut pandang society (masyarakat) yang artinya proses dimana seorang konsumen atau kelompok dalam memenuhi kebutuhan dan keinginannya melalui pencipta, penawaran, dan pertukaran atas barang dan jasa yang dibutuhkan. Sedang dari sudut pandang manajerial, pemasaran adalah suatu proses merencanakan konsep, harga, promosi, dan distribusi ide, penciptaan peluang yang memuaskan untuk individu dan sesuai dengan tujuan organisasi perusahaan."
\end{abstract}

Dari beberapa definisi yang telah dikemukakan, dapat disimpulkan bahwa pemasaran adalah ujung tombak dari serangkaian kegiatan usaha, baik yang bergerak dalam bidang jasa ataupun barang. Dikatakan sebagai ujung tombak karena pemasaran adalah barometer atau standardisasi dari keberhasilan suatu usaha dalam meraih pangsa pasar yang seluas-luasanya. Tujuan dari para produsen adalah kemampuan meracuni imajinasi konsumen dengan segala macam produk yang ditawarkan, pengemasan barang (packing design product), sampai mempromosikan barang. Dengan adanya bauran pemasaran diharapkan dapat mempertahankan kelangsungan hidup perusahaan, berkembang dalam usaha-usaha, dan pada akhirnya dapat mencapai laba semaksimal mungkin.

Untuk memahami pemasaran yang andal harus adanya kepuasan yang dirasakan oleh konsumen, menimbulkan respons positif berupa terjadinya pembelian ulang, dan menganjurkan konsumen lain agar membeli produk yang sama. Keuntungan berlipat ganda akan diperoleh produsen, melalui penyebaran informasi positif dari konsumen ke konsumen lain. 
Sepeti yang telah dijelaskan, bahwa proses pemasaran adalah proses tentang cara pengusaha dapat memengaruhi konsumen agar para konsumen tersebut menjadi tahu, senang, lalu membeli produk yang ditawarkan, dan akhirnya puas sehingga mereka akan selalu menggunakan produk tersebut. Salah satu kegiatan kegiatan yang sangat menentukan keberhasilan perusahaan untuk memenuhi tujuan yang telah ditetapkan adalah marketing mix dengan beberapa variabel yang dapat digunakan.

Pengertian marketing mix menurut Swastha (1999:42) sebagai berikut: "Marketing mix adalah kombinasi dari empat variabel atau kegiatan yang merupakan inti dari sistem pemasaran perusahaan, yaitu produk, struktur harga, kegiatan promosi, dan sistem distribusi.” Untuk mengetahui gambaran tentang variabel-variabel marketing mix, berikut dijelaskan masing-masing variabel tersebut.

Pertama, produk (product), adalah kumpulan/kesatuan atribut-atribut yang secara bersamasama memuaskan kebutuhan seseorang, baik yang dapat terlihat maupun tidak seperti warna, pembungkusan, harga, prestasi, manfaat, dan sebagainya. Jadi produk adalah segala sesuatu yang ditawarkan yang mampu menarik konsumen dan kemudian membuat konsumen tersebut terdorong untuk membelinya dan setelah membeli mereka akan puas sehingga akan terjadilah pembelian yang berulang-ulang oleh konsumen terhadap produk tersebut.

Kedua, harga (price), harga adalah sejumlah uang (ditambah beberapa barang kalau ada mungkin) yang dibutuhkan untuk mendapatkan sejumlah kombinasi dari barang beserta pelayananya. Penetapan harga yang terlalu tinggi ataupun terlalu rendah akan berakibat kurang menguntungkan bagi perusahaan. Untuk itu, perusahaan biasanya mengadakan percobaan untuk menguji pasarnya, apakah konsumen menerima atau menolak. Jika konsumen menerima penawaran tersebut, berarti harga yang ditetapkan sudah layak. Namun jika mereka menolak, biasanya harga itu akan diubah dengan cepat.

Ketiga, promosi (promotion) merupakan kegiatan yang dilakukan untuk memengaruhi konsumen agar mereka dapat mengenal produk dan jasa yang ditawarkan perusahaan kepada mereka dan kemudian mereka akan senang lalu membeli barang dan jasa tersebut. Promosi juga merupakan kegiatan untuk menyebarluaskan informasi tentang barang jasa yang dijual dengan maksud untuk merubah pola perilaku konsumen. Berbagai informasi yang diberikan kepada calon pembeli sangat memengaruhi keputusan mereka tentang pengalokasian dana yang mereka miliki. Mereka akan memasukkan barang atau jasa yang mereka ketahui ke daftar pertimbangan, lalu memilih kombinasi yang paling optimal. Oleh karena itu, penjual harus melakukan usaha yang efektif dalam membuat konsumen mengetahui tentang: (a) barang atau jasa yang ditawarkan. Ini menyangkut banyak hal seperti karakteristik fisik, disain, pilihan warna, kualitas, harga, manfaat, dan sebagainya. (b) yang membuat dan yang menjual; ini menyangkut kepuasan konsumen. Mereka merasa aman kalau mengetahui yang membuat dan menjual produk atau jasa tersebut. Ada tiga fungsi utama yang dipegang kegiatan promosi. Ketiga fungsi itu adalah mencari dan mendapatkan perhatian (attention) dari calon pembeli; menciptakan dan menumbuhkan minat pada diri calon pembeli; dan mengembangkan rasa ingin tahu (desire) calon pembeli untuk memiliki barang yang ditawarkan.

Keempat, distribusi (distribution) adalah saluran yang digunakan oleh produsen untuk menyalurkan barang/jasa tersebut dari produsen sampai ke konsumen atau pengguna industri. Dalam pencapaian tujuan dan sasaran perusahaan untuk menyalurkan barang atau jasa digunakan kegiatan distribusi. Distribusi merupakan struktur yang menggambarkan alternatif saluran yang dipilih, dan menggambarkan situasi pemasaran yang berbeda oleh berbagai macam perusahaan atau lembaga usaha (produsen, pedagang besar, dan pengecer). Ada tiga keputusan yang berkaitan dengan distribusi yang biasa disebut "place decision", yaitu: sistem angkutan perusahaan, sistem penyimpanan, sistem pemilihan saluran distribusi.

Lebih lanjut penelitian membahas salah satu variabel dalam marketing mix, yaitu promosi (promotion) sebagai analisis yang digunakan lebih lanjut. Stanton mengemukakan pendapatnya 
tentang promotional mix yang dikutip oleh Swastha (1999:238) sebagai berikut: "Promotional mix adalah kombinasi strategis yang paling baik dari variabel-variabel periklanan, personal selling, dan alat promosi yang lain, yang semuanya direncanakan untuk mencapai tujuan program penjualan.” Walaupun secara umum bentuk-bentuk promosi memiliki fungsi yang sama, bentuk-bentuk tersebut dapat dibedakan berdasarkan tugas-tugas khususnya. Untuk itu akan dibahas tentang variabel-variabel promotional mix sebagai berikut.

Pertama, periklanan (advertising), adalah komunikasi nonindividu, dengan sejumlah biaya, melalui media yang dilakukan oleh perusahaan, lembaga non-laba, serta individu-individu. Iklan merupakan salah satu bentuk promosi yang paling banyak digunakan perusahaan dalam mempromosikan produknya. Iklan adalah bentuk komunikasi tidak langsung, yang didasari pada informasi tentang keunggulan atau keuntungan suatu produk, yang disusun sedemikian rupa sehingga menimbulkan rasa menyenangkan yang akan mengubah pikiran seseorang untuk melakukan pembelian. Beberapa fungsi iklan adalah berikut ini. Pertama adalah untuk memberikan informasi. Iklan dapat memberikan informasi lebih banyak daripada media lainnya, baik tentang barang, harga maupun informasi lain yang mempunyai kegunaan bagi konsumen. Tanpa adanya informasi seperti itu orang akan segan atau tidak akan mengetahui banyak tentang suatu barang. Kedua, fungsi iklan adalah untuk membujuk/memengaruhi. Periklanan tidak hanya bersifat memberitahu saja, tetapi juga bersifat membujuk terutama kepada pembeli-pembeli potensial, dengan menyatakan bahwa suatu produk adalah lebih baik daripada produk lain. Fungsi ketiga adalah menciptakan kesan (image). Dengan sebuah iklan, orang akan mempunyai suatu kesan tertentu tentang barang/jasa yang diiklankan. Dalam hal ini, pemasang iklan selalu berusaha untuk menciptakan iklan yang sebaik-baiknya, dengan menggunakan warna, ilustrasi, bentuk, dan layout yang menarik. Keempat, iklan berfungsi untuk memuaskan keinginan. Sebelum memilih dan membeli produk, kadang-kadang orang ingin diberitahu lebih dulu tentang barang atau jasa yang ditawarkan atau ingin dibujuk untuk melakukan sesuatu yang lebih baik bagi mereka atau bagi masyarakat. Jadi periklanan merupakan suatu alat yang dapat dipakai untuk mencapai tujuan; dan tujuan itu sendiri berupa pertukaran yang saling memuaskan. Fungsi kelima, periklanan merupakan alat komunikasi. Periklanan adalah suatu alat untuk membuka komunikasi dua arah antara penjual dan pembeli, sehingga keinginan mereka dapat terpenuhi dalam cara yang efesien dan efektif. Inisiatif periklanan tidak selau datang dari pihak penjual, tetapi pembeli pun sering menggunakan iklan untuk kepentingannya, misalnya mencari pekerjaan.

Kedua, penjualan individu (personal selling) adalah interaksi antarindividu, yang saling bertemu muka untuk menciptakan, memperbaiki, menguasai, atau mempertahankan hubungan pertukaran yang saling menguntungkan dengan pihak lain. Sifat-sifat personal selling antara lain: Personal confrontation, yaitu adanya hubungan yang hidup, langsung, dan interaktif antara 2 orang atau lebih; Cultivation, yaitu sifat memungkinkan berkembanganya segala macam hubungan, mulai dari sekedar hubungan jual beli sampai dengan suatu hubungan yang lebih akrab; Response, yaitu situasi yang seolah-olah mengharuskan pelanggan untuk mendengar, memperhatikan, dan menanggapi. Oleh karena itu, sifat-sifat tersebut mempunyai kelebihan dan lebih fleksibel karena penjual dapat mengamati reaksi pelanggan, mengetahui keinginan konsumen, motif, dan perilaku konsumen. Personal selling merupakan suatu cara promosi yang menggunakan komunikasi langsung. Di sini penjual dengan aktif mendatangi konsumen dan menawarkan produk agar terjadi pembelian.

Ketiga adalah promosi penjualan (sales promotion). Nickels dalam Swastha (1999:279) promosi penjualan didefinisikan sebagai berikut: "Promosi penjualan adalah kegiatan-kegiatan pemasaran selain personal selling, periklanan, dan publisitas, yang mendorong efektivitas pembelian konsumen dan pedagang dengan menggunakan alat-alat seperti peragaan, pameran, demonstrasi, dan sebagainya." Promosi penjualan merupakan bentuk persuasi langsung melalui penggunaan berbagai insentif yang dapat diatur untuk merangsang pembelian produk dengan segera untuk meningkatkan jumlah barang yang dibeli pelanggan. Adapun tujuan dari promosi penjualan adalah menarik para pembeli baru, memberikan hadiah/penghargaan kepada konsumen-konsumen atau pelanggan, meningkatkan daya pembelian ulang dari konsumen lama, menghindarkan konsumen lari ke merek 
lain, mempopulerkan merek atau meningkatkan loyalitas, dan meningkatkan volume penjualan jangka pendek dalam rangka memperluas market share jangka panjang.

Keempat adalah hubungan masyarakat (public relations) dan publisitas (publicity). Hubungan Masyarakat (public relations) dapat didefinisikan fungsi manajemen yang memberikan penilaian tentang sikap masyarakat, identitas kebijaksanaan dan prosedur dari individu atau organisasi dengan keinginan masyarakat, dan melakukan program tindakan untuk mendapatkan pengertian serta pengakuan masyarakat. Humas merupakan satu bagian atau satu departemen yang bertanggung jawab mendengarkan dan menampung segala kritik, keluhan ataupun saran dari masyarakat. Humas tidak selalu merupakan alat promosi, tetapi yang penting harus dapat menyesuaikan organisasi dengan kebutuhan masyarakat. Publisitas (publicity) adalah sebuah informasi tentang seseorang, barang atau organisasi yang disebarluaskan ke masyarakat melalui media tanpa dipungut biaya, ataupun tanpa pengawasan dari sponsor. Publisitas merupakan pemanfaatan nilai-nilai berita terkandung dalam suatu produk untuk membentuk citra produk yang bersangkutan. Publisitas mempunyai kredibilitas yang lebih baik, karena pembenaran (baik langsung atau tidak langsung) dan pesan publisitas yang dimasukkan dalam berita atau artikel koran, tabloid, majalah, radio, dan televisi, maka khalayak tidak memandang sebagai komunikasi promosi. Adapun keuntungan publisitas adalah publisitas dapat menjangkau orang-orang yang tidak mau membaca sebuah iklan; publisitas dapat ditempatkan pada halaman depan dari sebuah surat kabar atau pada posisi lain yang menyolok; lebih dapat dipercaya; publisitas jauh lebih murah karena dilakukan secara bebas, tanpa dipungut biaya.

Promosi merupakan salah satu faktor penentu keberhasilan suatu program pemasaran. Apapun tingkat kualitas suatu produk, jika konsumen belum pernah mendengar dan tidak yakin bahwa produk itu akan berguna atau tidak bagi mereka, mereka akan ragu untuk membelinya atau tidak sama sekali membeli. Dalam hal ini perusahaan melakukan komunikasi pemasaran untuk mendukung promosi dalam penyampaian kepada masyarakat.

Menurut Swastha (1999:234) komunikasi pemasaran adalah: "Sebuah kegiatan komunikasi yang dilakukan oleh pembeli dan penjual, dan merupakan kegiatan yang membantu dalam pengambilan keputusan di bidang pemasaran serta mengarahkan pertukaran agar lebih memuaskan dengan cara menyadarkan semua pihak untuk berbuat lebih baik”. Ada tiga unsur pokok dalam struktur proses komunikasi pemasaran, yaitu: pertama, pelaku komunikasi, yang terdiri dari pengirim (sender) atau komunikator yang menyampaikan pesan dan penerima (receiver) atau komunikan. Kedua, material komunikasi, beberapa material komunikasi pemasaran yang penting adalah gagasan (materi pokok yang hendak disampaikan pengirim), pesan (himpunan berbagai simbol - oral, verbal, atau nonverbal dari suatu gagasan), media yaitu pembawa pesan komunikasi, response yaitu reaksi pemahaman atas pesan yang diterima oleh penerima, feed-back yaitu pesan umpan balik dari sebagian atau keseluruhan respons yang dikirim kembali oleh penerima, gangguan yaitu segala sesuatu yang dapat menghambat kelancaran proses komunikasi. Ketiga, proses komunikasi, adalah proses penyampaian pesan dari pengirim kepada konsumen maupun pengiriman kembali respons dari penerima kepada pengirim memerlukan dua kegiatan, yaitu: Encoding adalah proses merancang atau mengubah gagasan secara simbolik menjadi suatu pesan untuk disampaikan kepada penerima dan Decoding adalah proses menguraikan atau mengartikan simbol sehingga pesan yang diterima dapat dipahami.

Pemasaran bukan saja melibatkan hasil-hasil produksi berupa benda-benda yang berwujud yang disalurkan oleh produsen tetapi juga mencakup bidang jasa juga. Sifat perusahaan yang menghasilan jasa adalah jasa itu tidak bisa ditimbun atau ditumpuk dalam gudang, seperti halnya barang-barang lainnya sambil menunggu penjualan. Swastha (1999:318) mendefinisikan "Jasa adalah barang yang tidak kentara (intangible product) yang dibeli dan dijual di pasar melalui suatu transaksi pertukaran yang saling memuaskan.” Dari pengertian tersebut dapat ditarik kesimpulan bahwa (a) jasa merupakan produk tidak berwujud yang dilakukan dan bukannya di produksi dan (b) nilai dan 
keuntungan dari suatu jasa dapat berbeda-beda di antara pemakainya karena sebagian sumber (input) melaksanakan jasa dari pembeli.

Menurut Kotler dalam Hurriyati (2005:28), jasa memiliki empat cirri utama yang sangat mempengaruhi rancangan program pemasaran sebagai berikut. Pertama, tidak berwujud; produk jasa tidak sama dengan produk fisik, artinya konsumen tidak dapat melihat, mencium, meraba, mendengar, dan merasakan hasilnya sebelum membelinya. Untuk itu konsumen akan mencari informasi tentang jasa tersebut, seperti lokasi perusahaan, para penyedia dan penyalur jasa, peralatan dan komunikasi yang digunakan serta harga produk jasa tersebut. Agar dapat meningkatkan kepercayaan calon konsumen, perusahaan memerlukan: meningkatkan visualisasi jasa yang tidak berwujud menjadi berwujud, menekankan pada manfaat yang diperoleh, menciptakan suatu nama merek (brand name) bagi jasa, memakai nama orang terkenal untuk meningkatkan kepercayaan konsumen. Kedua, tidak terpisahkan; jasa tidak dapat dipisahkan dari sumbernya, yaitu perusahaan jasa yang menghasilkannya. Jasa diproduksi dan dikonsumsi pada saat bersamaan. Jika konsumen membeli suatu jasa, ia akan berhadapan langsung dengan sumber jasa tersebut. Ketiga, bervariasi; jasa yang diberikan sering berubah-ubah tegantung dari dari siapa yang menyajikan, serta kapan dan di mana penyaji jasa tersebut dilakukan. Untuk itu, tiga hal yang perlu dilakukan dalam meningkatkan pengendalian kualitas (menurut Tjiptono dalam Hurriyati, 2005), yaitu: melakukan investasi dalam seleksi dan pelatihan personel yang baik, melakukan standarisasi proses produksi jasa, dan memantau kepuasan pelanggan melalui system saran dan keluhan, survey pelanggan, dan comparison shopping, sehingga pelayanan yang kurang baik dapat diketahui dan dapat diperbaiki. Keempat, mudah rusak, jasa tidak dapat disimpan atau mudah rusak sehingga tidak dapat dijual pada musim mendatang. Keadaan ini bukan suatu masalah apabila permintaan stabil, sehingga mudah untuk persiapan pelayanan sebelumnya. Untuk itu, diperlukan perencanaan produk, penetapan harga, serta program promosi yang tepat untuk mengatasi ketidak sesuaian antara permintaan dan penawaran.

Industri jasa pada saat ini merupakan sektor ekonomi yang sangat besar dan tumbuh sangat pesat. Dipandang dari konteks globalisasi, pesatnya pertumbuhan bisnis jasa antarnegara ditandai dengan meningkatnya itentensitas pemasaran lintas negara serta terjadinya aliansi berbagai penyedia jasa di dunia.

\section{Hotel}

Kata hotel berasal dari bahasa Prancis, hostel, yang artinya rumah penginapan bagi orangorang yang sedang mengadakan perjalanan atau bepergian. Dalam perkembanganya definisi hotel didefinisikan sebagai berikut. Dalam Surat Keputusan No 241/II/1970, Rumekso (2001), mendefinisikan hotel adalah perusahaan yang menyediakan jasa dalam bentuk akomodasi serta menyediakan hidangan dan fasilitas lainnya di dalam hotel untuk umum yang memenuhi syarat comfort dan bertujuan komersial dalam jasa tersebut. Surat Keputusan Menparpostel No KM 37/PW.340/MPPT-86, tentang Peraturan Usaha dan Penggolongan Hotel, Bab I, Pasal 1, Ayat (b) dalam surat keputusan menyatakan bahwa hotel adalah suatu jenis akomodasi yang mempergunakan sebagian atau seluruh bangunan untuk menyediakan jasa penginapan, makanan dan minuman serta jasa penunjang lainnya bagi umum yang dikelola secara komersial (Sulastiyono, 2006). Sementara itu, menurut Hotel Proprietors Act, 95 dalam Sulastiyono (2006), hotel adalah suatu perusahaan yang dikelolah oleh pemiliknya dengan menyediakan pelayanan makan, minuman, dan fasilitas kamar untuk tidur kepada orang-orang yang sedang melakukan perjalan dan mampu membayar dengan sejumlah yang wajar sesuai dengan pelayanan yang diterima tanpa adanya perjanjian khusus. Dari ketiga pengertian tersebut, dapat disimpulkan bahwa hotel (1) suatu jenis akomadasi, (2) menggunakan sebagian atau seluruh bangunan yang ada, (3) menyediakan jasa penginapan, makanan dan minuman serta jasa penunjang lainnya, (4) disediakan bagi umum, (5) dikelola secara komersial. 
Berdasarkan lokasi, Alma (2004:290) mengemukakan bahwa hotel dapat dibagi menurut jenisnya sebagai berikut. Residential Hotel adalah hotel yang menerima tamu untuk tinggal dalam jangka waktu yang agak lama, tetapi tidak untuk menetap. Hotel ini pada dasarnya adalah rumahrumah berbentuk apartemen dengan kamar yang disewakan secara bulanan atau tahunan. Juga menyediakan restoran, dan kebersihan kamar. Transit Hotel, biasa juga disebut Commercial Hotel yaitu hotel yang menyediakan kamar dan makan pagi yang diperuntukkan bagi pengunjung yang sedang mengadakan perjalanan untuk keperluan bisnis dalam waktu relatif pendek. Hotel semacam ini biasanya terdapat di pusat kota atau pada kompleks perdagangan yang ramai, maupun dekat pelabuhan. Resort Hotel, biasa juga disebut seasonal hotel, yaitu menyediakan akomodasi pada musim tertentu. Hotel ini teletak pada daerah-daerah peristirahatan, juga ada ruang sidang. Motel (motor hotel) merupakan penginapan yang diperuntukan bagi pelaku perjalanan atau turis yang mengadakan perjalanan di sepanjang highway, yang menghubungkan antara dua kota.

\section{Hipotesis}

Hipotesis penelitian yang akan diuji yaitu: diduga bahwa bauran promosi yang dilakukan oleh Hotel Benua Bandung (periklanan, penjualan individu, promosi penjualan) mempunyai pengaruh terhadap peningkatan volume penjualan kamar. Dengan demikian, kerangka berpikir penelitian adalah seperti Gambar 1 berikut.

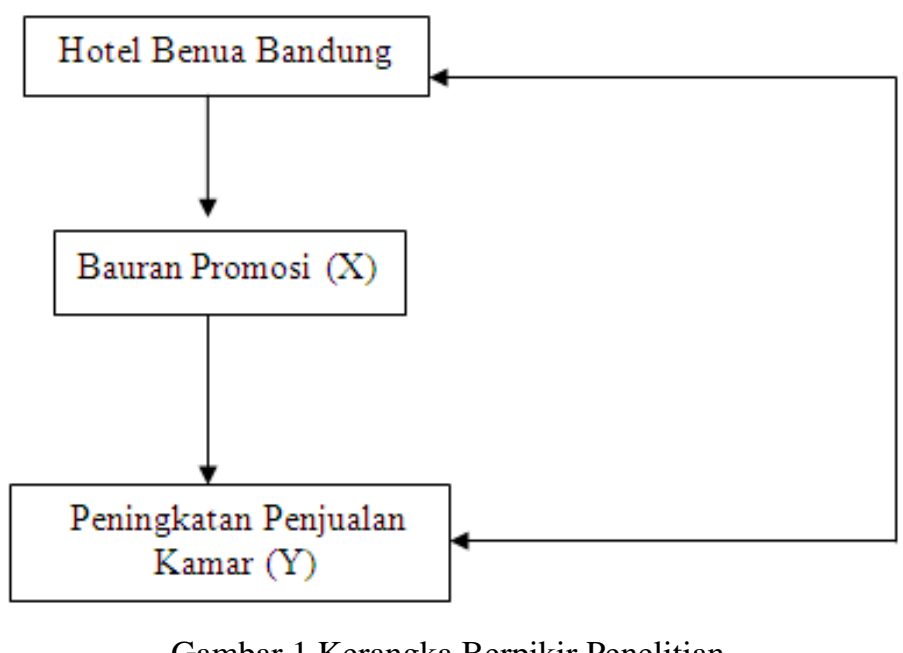

Gambar 1 Kerangka Berpikir Penelitian

\section{METODE PENELITIAN}

Penelitian dilakukan di Hotel Benua Bandung. Adapun waktu yang dibutuhkan untuk mengadakan penelitian ini kurang lebih tiga bulan. Untuk memperoleh data dan informasi yang diperlukan dalam penelitian ini, maka digunakan metode: Observasi, pengumpulan data dengan cara melihat langsung kepada objek; Wawancara langsung dan mendengarkan secara langsung/keterangan yang dibutuhkan; Dokumentasi, metode yang digunakan untuk memperoleh data melalui dokumen yang ada hubungannya dengan masalah yang diteliti.

Jenis data yang digunakan adalah data kuantitatif, yaitu data yang dapat dihitung atau berupa angka-angka yang diperoleh dari dokumen-dokumen dan data lapangan dan data kualitatif, yaitu data mengenai keadaan objek penelitian, dalam hal ini Hotel Benua Bandung. Sumber data yang 
dipergunakan dalam penulisan ini adalah data sekunder, yaitu data yang diperoleh dari dokumen atau laporan tertulis lainnya yang berhubungan erat dengan penulisan ini.

Adapun metode analisis yang digunakan untuk pengujian dan pembuktian hipotesis yaitu, pertama analisis deskriptif. Dalam upaya pemecahan masalah yang dihadapi perusahaan, dalam hal ini Hotel Benua Bandung, metode analisis yang digunakan pada tahap pertama adalah analisis deskriptif yang menguraikan secara kualitatif relevansi bauran promosi yang digunakan pada Hotel Benua Bandung dengan volume penjualan kamarnya. Sedangkan analisis dekriptif adalah metode-metode yang berkaitan dengan pengumpulan dan penyajian suatu gugus data sehingga memberikan informasi yang berguna (Walpole, 1995). Analisis dekriptif memberikan informasi mengenai sekumpulan data dan mendapatkan gagasan untuk keperluan analisis selanjutnya, jika diperlukan analisis ini meliputi penyusunan ukuran pemusatan, ukuran penyebaran, tabel, diagram, dan grafik. Selain itu, regresi sederhana, persamaan analisis regresi sederhana digunakan untuk menentukan apakah volume penjualan secara kuantitatif di Hotel Benua Bandung dipengaruhi oleh bauran promosi (dalam hal ini periklanan, penjualan individu, dan promosi penjualan). Regresi yang digunakan oleh Sugiyono (2001:169) adalah:

$$
\mathrm{Y}=\mathrm{a}+\mathrm{bx}
$$

dengan

$$
\begin{aligned}
& \mathrm{Y}=\text { Volume penjualan kamar } \\
& \mathrm{a}=\text { Konstanta } \\
& \mathrm{b}=\text { Koefisien regresi } \\
& \mathrm{x}=\text { Biaya promosi }
\end{aligned}
$$

Untuk menguji hipotesis digunakan uji korelasi parsial (r) dan determinasi (R) untuk melihat pengaruh dari variabel dependen $(\mathrm{X})$ terhadap variabel independen $(\mathrm{Y})$ dalam model regresi berganda diatas. Pengujian hipotesis dilanjutkan dengan melakukan uji t (variabel bersama) yang berfungsi menguji signifikansi dependen yang ada.

Definisi operasional yang dipakai dalam penelitian ini adalah: Bauran Promosi merupakan gabungan berbagai jenis promosi yang ada untuk suatu produk yang sama agar hasil dari kegiatan promosi yang dilakukan dapat memberikan hasil yang maksimal. Periklanan (advertising) adalah komunikasi non individu, dengan sejumlah biaya, melalui media yang dilakukan oleh perusahaan, lembaga nonlaba, serta individu-individu. Penjualan Individu (personnal selling) adalah interaksi antar individu, saling bertemu muka yang ditujukan untuk menciptakan, memperbaiki, menguasai, atau mempertahankan hubungan pertukaran yang saling menguntungkan dengan pihak lain. Promosi Penjualan adalah kegiatan-kegiatan pemasaran selain personal selling, periklanan, dan publisitas, yang mendorong efektivitas pembelian konsumen dan pedagang dengan menggunakan alat-alat seperti peragaan, pameran, demonstrasi, dan sebagainya.

\section{HASIL DAN PEMBAHASAN}

\section{Promosi yang Dilakukan Perusahaan}

Kegiatan pemasaran saat ini merupakan hal yang sangat penting bagi usaha perhotelan. Makin ketatnya persaingan antara perusahaan sejenis mengharuskan perusahaan harus jeli dalam membuat keputusan tentang produk jasa yang akan ditawarkan kepada konsumen. Dengan makin ketatnya persaingan, persoalan yang mengemuka sekarang adalah bagaimana dan cara apa yang dapat 
digunakan perusahaan agar masyarakat sebagai konsumen pengguna jasa mengetahui mutu, jenis, dan kualitas produk jasa tersebut. Sesuai dengan fokus penelitian dalam penelitian ini, maka salah satu cara yang dapat ditempuh adalah dengan melakukan promosi.

Promosi merupakan salah satu aspek yang penting dalam pemasaran karena hal tersebut merupakan salah satu cara untuk memperlancar suatu produk atau jasa kepada konsumen atau pemakai. Promosi yang dilakukan oleh perusahaan tersebut haruslah dapat mempengaruhi konsumen secara rasional dan emosional, khususnya bagi konsumen yang menjadi sasaran perusahaan. Agar konsumen berminat untuk menggunakan sekaligus mencintai suatu produk atau jasa, maka konsumen sebelum membeli dan menggunakan terlebih dahulu harus mengenal apa, kapan dan di mana, serta bagaimana produk itu digunakan. Untuk itu perusahaan harus menonjolkan keunikan, keistimewaan dan kelebihan produk atau jasa yang dihasilkan dibanding dengan produk yang lainnya.

Dalam kegiatan promosi ada empat bentuk promosi yang dapat digunakan untuk mempengaruhi calon pembeli dalam menggunakan produk atau jasa. Keempat bentuk promosi (promotional mix) tersebut adalah Advertising, Personnal selling, Sales promotion, Publicity. Namun demikian, publikasi (publicity) tidak digunakan dalam melakukan usaha untuk memasarkan produknya. Di luar kenyataan tersebut tampak bahwa Hotel Benua Bandung melakukan kegiatan promosi terus menerus dan telah banyak mengeluarkan biaya yang cukup besar setiap tahunnya. Hal ini dimaksudkan agar konsumen dapat lebih mengenal fasilitas-fasilitas dan produk atau jasa yang ditawarkan.

Kegiatan promosi yang dilakukan oleh suatu perusahaan akan ikut menunjang tercapainya tujuan perusahaan dalam meningkatkan volume penjualan yang telah ditetapkan. Dalam hal ini, Hotel Benua Bandung telah berusaha untuk mempertimbangkan mengenai efisiensi dan efektifitas dari kegiatan promosi tersebut. Efesiensi artinya dalam pelaksanakan kegiatan promosi biaya yang dikeluarkan, diusahakan seefesien atau seminimal mungkin, tetapi dengan biaya tersebut tidak mempengaruhi hasil yang telah ditetapkan. Sedangkan efektif adalah dengan pelaksanaan promosi dapat mencapai suatu target yang telah ditentukan oleh perusahaan.

Promosi yang dilakukan oleh Hotel Benua Bandung dalam memasarkan produk atau jasa yang dihasilkan lebih banyak menggunakan sales promotion, advertising dan personal selling sebagai alat promosinya. Penentuan atau pemilihan media promosi untuk menyampaikan pesan kepada konsumen dapat membantu perusahaan dalam pengambilan keputusan promosi yang akan dilakukan oleh perusahaan. Dalam pemilihan media promosi yang akan digunakan, pada umumnya Hotel Benua Bandung mempertimbangkan beberapa faktor: anggaran biaya promosi, kedudukan produk dalam Produk Life Cycle, keadaan persaingan di pasar, target promosi, sifat produk yang ditawarkan.

Setelah melihat faktor-faktor dalam pemilihan media tersebut, media promosi yang digunakan Hotel Benua Bandung dalam melakukan kegiatan di bidang promosi terutama periklanan adalah: (1) Radio; melalui media ini, Hotel Benua Bandung memasarkan produk jasanya untuk memikat calon pembeli karena media ini sangat mudah dijangkau lapisan masyarakat. (2) Surat kabar; diharapkan melalui media ini, konsumen atau pelanggan dapat menarik konsumen karena media ini dianggap dapat digunakan lebih lama dan dibaca berulang-ulang untuk jangka waktu yang lama sehingga lebih banyak dan sering dilihat dan dibaca orang. (3) Hotel Directory; layanan bentuk sarana promosi ini, memuat informasi tentang alamt, lokasi, jenis, produk, fasilitas dan bentuk pelayanan yang dapat diberikan kepada calon tamu.

Sedangkan dalam sales promotion, Hotel Benua Bandung melakukan promosi untuk menarik konsumen dengan mengadakan Sales Blitz, pemberian diskon atau potongan khusus untuk setiap kamar yang berlaku pada tiap waktu tertentu, atau dengan pengadaan voucher menginap yang berlaku setiap saat untuk digunakan. Sales blitz di sini adalah bertujuan untuk mendengar langsung masukan atau komentar dari klien baru atau tamu regular. Sales blitz biasa dilakukan untuk company (event). 
Personal selling yang dilakukan oleh Hotel Benua Bandung adalah telemarketing. Telemarketing biasanya dilakukan untuk tamu perorangan melalui telpon untuk memanggil kembali tamu-tamu regular perorangan yang sudah lama tidak datang ke hotel. Personal selling bertujuan untuk menciptakan, memperbaiki, menguasai, atau mempertahankan hubungan pertukaran yang saling menguntungkan dengan pihak lain.

Peningkatan penjualan kamar merupakan target dan tujuan dari Hotel Benua Bandung. Perusahaan akan selalu berusaha agar penjualan kamar terus meningkat setiap tahunnya. Berdasarkan data yang yang telah dikumpulkan dalam penelitian, Tabel 1 berikut memperlihatkan hasil penjualan kamar Hotel Benua Bandung selama lima tahun terakhir (2006-2010).

Tabel 1 Perkembangan Penjualan Kamar di Hotel Benua Bandung Tahun 2006-2010

\begin{tabular}{ccr} 
Tahun & $\begin{array}{c}\text { Volume Penjualan } \\
\text { ( Rp ) }\end{array}$ & $\begin{array}{r}\text { Pertumbuhan } \\
(\mathbf{\%})\end{array}$ \\
\hline 2006 & 534.501 .000 & - \\
2007 & 1.789 .271 .000 & 234,75 \\
2008 & 2.323 .233 .000 & 29,84 \\
2009 & 2.409 .820 .000 & 3,72 \\
2010 & 2.549 .518 .000 & 5,79 \\
\hline
\end{tabular}

(Sumber: Hotel Hotel Benua Bandung, tahun 2011)

Dari data pada tabel, tampak selama lima tahun terakhir (2006-2010) perkembangan penjualan kamar mengalami peningkatan setiap tahunnya. Pada 2006 volume penjualan sebesar Rp534.501.000 kemudian pada 2007 mengalami kenaikan sebesar Rp1.789.271.000. Pada 2008 penjualan mengalami kenaikan Rp2.323.233.000, pada 2009 mengalami kenaikan lagi sebesar Rp2.409.820.000 dan tahun 2010 mengalami kenaikan sebesar Rp2.549.518.000.

Selama lima tahun terakhir Hotel Benua Bandung melakukan kegiatan pemasarannya melalui bauran promosi berupa periklanan (advertising), promosi penjualan (sales promotion) dan penjualan individu (personal selling) secara terus menerus dan telah mengeluarkan biaya yang cukup besar. Untuk melihat gambaran biaya-biaya promosi yang telah dikeluarkan selama lima tahun terakhir dapat dilihat pada Tabel 2 berikut.

Tabel 2 Perkembangan Biaya Promosi di Hotel Benua Bandung Tahun 2006-2010

\begin{tabular}{ccrr}
\hline TAHUN & $\begin{array}{c}\text { BIAYA PROMOSI } \\
\text { ( Rp) }\end{array}$ & \multicolumn{2}{c}{$\begin{array}{c}\text { PERTUMBUHAN } \\
\text { ( \%) }\end{array}$} \\
\hline 2006 & 62.302 .083 & - \\
2007 & 67.233 .022 & 7,91 \\
2008 & 70.253 .152 & 4,49 \\
2009 & 72.574 .735 & 3,30 \\
2010 & 80.254 .869 & 10,58 \\
\hline
\end{tabular}

(Sumber: Hotel Benua Bandung, tahun 2011)

Dari data Tabel 2 terlihat bahwa selama lima tahun terakhir (2006-2010), biaya promosi melalui periklanan, sales promotion dan personal selling yang dikeluarkan oleh perusahaan Hotel Benua Bandung mengalami peningkatan setiap tahunnya. Pada 2006 biaya promosi yang dikeluarkan sebesar Rp62.302.083, kemudian meningkat menjadi Rp67.233.022 pada 2007. Pada 2008 mengalami 
kenaikan menjadi Rp70.253.152, tahun 2009 mengalami kenaikan menjadi Rp72.574.735. Terakhir pada 2010 mengalami kenaikan sebesar Rp80.254.869.

\section{Pengaruh Bauran Promosi terhadap Volume Penjualan}

Untuk dapat mengetahui seberapa jauh pengaruh promosi terhadap volume penjualan kamar pada Hotel Hotel Benua Bandung, penelitian mengumpulkan data yang dapat menunjang penelitian ini, yaitu data Volume Penjualan dan Data Biaya promosi selama lima tahun terakhir (2006-2010).

Tabel 3 Volume Penjualan dan Biaya Promosi Total di Hotel Benua Bandung Tahun 2006-2010

\begin{tabular}{ccc} 
Tahun & $\begin{array}{c}\text { Volume Penjualan } \\
\text { ( Rp ) }\end{array}$ & $\begin{array}{c}\text { Biaya Promosi } \\
\text { ( Rp ) }\end{array}$ \\
\hline 2006 & 534.501 .000 & 62.302 .083 \\
2007 & 1.789 .271 .000 & 67.233 .022 \\
2008 & 2.323 .233 .000 & 70.253 .152 \\
2009 & 2.409 .820 .000 & 72.574 .735 \\
2010 & 2.549 .518 .000 & 80.254 .869 \\
\hline
\end{tabular}

(Sumber: Data I dan Data II)

Adapun analisis yang digunakan untuk mengetahui hubungan antara volume penjualan dan biaya yang termasuk dalam bauran promosi yang menjadi objek penelitian (periklanan, penjualan individu dan promosi penjualan) adalah sebagai berikut.

\section{Regresi}

Analisis data kuantitatif dimaksud untuk memperhitungkan atau memperkirakan besarnya pengaruh secara kuantitatif dari perubahan suatu kejadian terhadap kejadian lainnya. Hasil dari analisis tersebut dapat dipergunakan untuk mengevaluasi dari suatu kebijakan. Analisis tersebut bertujuan untuk menyelidiki jika variabel yang diteliti berhubungan satu sama lain. Hasil dari analisis kuantitatif dapat menjawab jika hasil analisis tidak sesuai dengan yang diharapkan semula kemudian perlu diadakan perubahan atau penyesuaian terhadap kebijakan yang bersangkutan. Untuk itu, penelitian menggunakan metode analisis regresi linier sederhana dari biaya promosi sebagai variabel terikat (X) dan volume penjualan sebagai variabel bebas (Y). Setelah memasukkan data pada tabel sebelumnya dalam program SPSS didapatkan output sebagai berikut.

Tabel 4 Hasil Regresi Linier Sederhana dari Biaya Promosi dan Volume Penjualan

\begin{tabular}{|c|c|c|c|c|c|c|}
\hline \multirow[t]{2}{*}{ Model } & & \multicolumn{2}{|c|}{ Unstandardized Coefficients } & \multirow{2}{*}{$\begin{array}{c}\begin{array}{c}\text { Standardized } \\
\text { Coefficients }\end{array} \\
\text { Beta }\end{array}$} & \multirow[b]{2}{*}{$\mathbf{t}$} & \multirow[b]{2}{*}{ Sig. } \\
\hline & & $\mathbf{B}$ & Std. Error & & & \\
\hline \multirow[t]{2}{*}{1} & (Constant) & -5569500199.131 & 2628557644.523 & & -2.119 & .124 \\
\hline & Promosi & 106.217 & 37.140 & .855 & 2.860 & .065 \\
\hline
\end{tabular}

a. Dependent Variable: Penjualan

Dari output tersebut diperoleh persamaan regresi yaitu $Y=-5.569 .500 .199+106.217 X$. Hasil regresi ini menunjukkan pengaruh dari variabel bauran promosi berpengaruh positif terhadap penjualan. Hasil regresi ini berikutnya menjadi dasar dari analisis dan pembahasan selanjutnya. 


\section{Korelasi}

Untuk mengetahui hubungan keeratan antara variabel dependen (periklanan, penjualan individu dan promosi penjualan) dengan biaya independen (volume penjualan), dapat digunakan analisis koefisien korelasi (R) dan koefisien korelasi parsial (r). Data hasil analisis koefisien korelasi parsial dapat diketahui dengan melihat output SPSS sebagai berikut.

Tabel 5 Hasil Analisis Koefisien Korelasi

Model Summary

\begin{tabular}{ccccc}
\hline Model & $\mathbf{R}$ & R Square & Adjusted R Square & $\begin{array}{c}\text { Std. Error of } \\
\text { the Estimate }\end{array}$ \\
\hline 1 & $.855^{\mathrm{a}}$ & .732 & .642 & 494669802.547 \\
\hline a. Predictors: (Constant), Promosi & &
\end{tabular}

Dari hasil perhitungan koefisien korelasi antara biaya promosi dengan volume penjualan kamar pada Hotel Hotel Benua Bandung, diperoleh koefisien korelasi (R) sebesar 0,855. Hal ini berhubungan juga dengan hasil koefisien determinasi $\left(\mathrm{R}^{2}\right)$ yang menyatakan bahwa variabel independen dapat menjelaskan sebesar 73,2\% dari hasil penjualan.

Dari hasil perhitungan korelasi tersebut dapat disimpulkan adanya hubungan yang kuat antara penjualan kamar dan biaya promosi yang dikeluarkan (yang diwakili oleh periklanan, penjualan individu dan promosi penjualan). Secara keseluruhan dapat dikatakan bahwa makin besar biaya promosi yang dikeluarkan, volume penjualan kamar akan makin meningkat. Sebaliknya jika biaya promosi yang dikeluarkan berkurang, volume penjualan kamar akan menurun.

Korelasi parsial (r) dari output SPSS berikutnya dapat dianalisis untuk melihat seberapa erat hubungan dari masing-masing variabel independen terhadap variabel dependennya sebagai berikut.

Tabel 6 Korelasi Pearson

\begin{tabular}{|c|c|c|c|}
\hline & & Penjualan & omosi \\
\hline \multirow[t]{2}{*}{ Pearson Correlation } & Penjualan & 1.000 & .855 \\
\hline & Promosi & .855 & 1.000 \\
\hline \multirow[t]{2}{*}{ Sig. (1-tailed) } & Penjualan & . & .032 \\
\hline & Promosi & .032 & . \\
\hline \multirow[t]{2}{*}{$\mathrm{N}$} & Penjualan & 5 & 5 \\
\hline & Promosi & 5 & 5 \\
\hline
\end{tabular}

Berdasarkan hasil Pearson Correlation terlihat bahwa variabel promosi sebesar 0,855 memiliki hubungan yang kuat terhadap penjualan.

\section{Uji-t}

Langkah terakhir dari pembahasan hasil regresi tersebut adalah menilai signifikansi hipotesis yang diajukan penulis dengan uji-t dengan melihat output SPSS berikut. 
Tabel 7 Uji-t

Coefficients $^{\mathrm{a}}$

\begin{tabular}{|c|c|c|c|c|c|c|}
\hline \multirow[b]{2}{*}{ Model } & & \multicolumn{2}{|c|}{ Unstandardized Coefficients } & \multirow{2}{*}{$\begin{array}{c}\begin{array}{c}\text { Standardized } \\
\text { Coefficients }\end{array} \\
\text { Beta } \\
\end{array}$} & \multirow[b]{2}{*}{$\mathbf{t}$} & \multirow[b]{2}{*}{ Sig. } \\
\hline & & B & Std. Error & & & \\
\hline \multirow[t]{2}{*}{1} & (Constant) & -5569500199.131 & 2628557644.523 & & -2.119 & .124 \\
\hline & Promosi & 106.217 & 37.140 & .855 & 2.860 & .065 \\
\hline
\end{tabular}

Dependent Variable: Penjualan

Dari nilai uji-t dapat disimpulkan bahwa variabel Promosi signifikan karena hanya nilai uji$t_{\text {hitung }}$-nya yang bernilai 0,065 . Hal ini berarti variabel dependen secara bersama-sama signifikan dan menerangkan variabel independen (Y) atau penjualan secara serentak. Dapat disimpulkan bahwa variabel Promosi (Periklanan, Penjualan Individu dan Promosi Penjualan) memiliki nilai yang signifikan dan memengaruhi terhadap variabel Penjualan dan mendukung hipotesis penelitian.

\section{SIMPULAN}

Berdasarkan data yang diperoleh dari hasil penelitian dan pembahasan Pengaruh Bauran Promosi terhadap Penjualan Kamar pada Hotel Benua Bandung, serta dengan menggunakan landasan teori yang berhubungan dengan penelitian, simpulan penelitian adalah sebagai berikut. Pertama, data yang diolah selama lima tahun terakhir menunjukkan usaha di Hotel Benua Bandung mengalami kenaikan volume penjualan kamar. Kedua, untuk saat ini kebijakan promosi yang dilakukan oleh perusahaan Hotel Benua Bandung adalah periklanan (advertising), penjualan individu (personal selling), dan promosi penjualan (sales promotion). Ketiga, berdasarkan hasil perhitungan analisis regresi terlihat adanya hubungan yang kuat dari nilai korelasi (R) antara bauran promosi yang dilakukan dengan peningkatan volume penjualan kamar. Hal ini didukung pula oleh hasil uji-t yang secara bersama-sama membuktikan bahwa hipotesis yang diajukan dalam penelitian ini dapat diterima.

\section{Saran}

Berdasarkan simpulan, saran-saran penelitian untuk tercapainya tujuan perusahaan yang telah ditetapkan adalah sebagai berikut. Pertama, sebagai suatu perusahaan yang bergerak di bidang jasa, Hotel Benua Bandung selain melaksanakan kegiatan promosi juga harus dapat menjaga grooming dan hospital industry. Hal itu karena faktor-faktir tersebut sebagai salah satu kunci utama keberhasilan suatu perusahaan jasa perhotelan. Contohnya, setiap karyawan memberikan service yang baik dan memuaskan sehingga tamu akan merasa nyaman dan terlindungi dan betah serta berminat untuk menggunakan akomodasi jasa tersebut. Kedua, karena biaya promosi mempunyai hubungan yang erat dan positif, yang dapat memengaruhi volume penjualan kamar, perusahaan harus lebih giat melakukan promosi sehingga pangsa pasar perusahaan semakin luas dan tujuan perusahaan yang telah ditetapkan dapat tercapai. Ketiga, publikasi (publication) sebagai salah satu bentuk bauran promosi sampai saat penelitian ini selesai dilakukan belum menjadi alternatif media promosi di Hotel Benua Bandung. Ke depannya, dengan melihat tingkat persaingan yang semakin meningkat tajam, sebaiknya publikasi menjadi salah satu alternatif promosi selain metoda yang telah dilakukan sekarang. Keempat, media promosi lainnya yang mungkin dapat menjadi alternatif adalah penggunaan media Internet, terutama situs media sosial seperti facebook dan twitter yang juga dapat menjadi alternatif promosi. Dengan makin tersebar dan makin murahnya akses Internet, baik melalui handphone, laptop, atau komputer desktop, media sosial ini diyakini juga dapat menunjang ekspos Hotel Benua Bandung di kalangan turis lokal maupun turis mancanegara yang akan berkunjung ke Bandung. 


\section{DAFTAR PUSTAKA}

Alma, B. (2004). Manajemen Pemasaran dan Pemasaran Jasa. Bandung: Alfabeta.

Hurriyati, R. (2005). Bauran Pemasaran dan Loyalitas Konsumen. Bandung: Alfabeta.

Khotijah, S. (2004). Smart Strategy of Marketing. Bandung: Alfabeta.

Rumekso. (2001). Housekeeping Hotel. Yogyakarta: Andi.

Sugiyono. (2001). Metode Penelitian Administrasi. Bandung: Alfabeta.

Sulastiyono, A. (2006). Manajemen Penyelenggaraan Hotel. Bandung: Alfabeta.

Swastha, B. (1999). Azas-Azas Marketing. Edisi Ketiga. Yogyakarta: Liberty.

Walpole, R. E. (1995). Pengantar Statistika. Edisi Ketiga. Jakarta: Gramedia Pustaka Utama. 